\title{
Autoria, identidade e alteridade: Entrevista com Bernardo Carvalho
}

\author{
Authorship, identity and alterity: an interview with Bernardo Carvalho
}

\author{
Christian Fischgold ${ }^{1}$
}

Sonia Aurora Miceli²

\begin{abstract}
Resumo:Nesta entrevista com Bernardo Carvalho, discutimos algumas questões recorrentes na sua literatura, quais sejam a relação com o outro e a sua representação, as possibilidades da linguagem literária e os conflitos culturais.

Palavras-chave: Bernardo Carvalho. Alteridade. Identidade.
\end{abstract}

Abstract: In this interview with Bernardo Carvalho, we discuss some recurring issues in his literature, such as the relationship with the other and its representation, the possibilities of literary language and cultural conflicts.

Keywords: Bernardo Carvalho. Alterity. Identity.

Autor de uma obra complexa e original, Bernardo Carvalho tem um papel de destaque na literatura brasileira contemporânea, tendo publicado obras que estimulam a reflexão sobre a criação literária, os conflitos culturais, as possibilidades e os limites da linguagem. De Aberração (1993) a Simpatia pelo demônio (2016), passando pelos incontornáveis Nove noites (2002) e Mongólia (2003), há um fio que parece ligar os contos e os romances que o autor foi publicando, a saber, a indagação acerca do humano, que põe a nu, por um lado, o seu carácter autodestrutivo, pelo outro, a inextricabilidade das noções de identidade e de alteridade - problemática que se reflete, naturalmente, na sua ideia de literatura. No dia 26 de março de 2017, em Lisboa, tivemos a oportunidade de conversar com o autor sobre essas e outras questões, tendo, como resultado, as páginas que se seguem.
CHRISTIAN RODRIGUES FISCHGOLD - Em entrevista para Beatriz Resende ${ }^{3}$ você disse que $O$ sol se põe em São Paulo foi pensado para ser uma reação à recepção de Nove Noites e Mongólia, "ao se dar conta que o efeito de realidade era o que havia interessado a muitos leitores", reduzindo o romance a um relato da realidade, como se a invenção, a criação e a imaginação fossem menos importantes. Qual é, afinal, o papel do leitor, e até que ponto os espaços vazios a serem preenchidos na sua obra são intencionais?

BERNARDO CARVALHO - Acho que a obra responde melhor que o autor. É uma obra cheia de lacunas e que pressupõe uma participação ativa do leitor. Na verdade, há um respeito pelo leitor como coautor da obra que é muito maior do que se eu estivesse atendendo a uma suposta demanda prévia do leitor.

\footnotetext{
1 Doutor e mestre em Literatura Comparada pela Universidade do Estado do Rio de Janeiro, Rio de Janeiro, Brasil. Atualmente na Universidade Estadual de Campinas, Instituto de Estudos da Linguagem, Campinas, SP, Brasil. ORCID: https://orcid.org/oooo-ooo26510-7963. E-mail: crf.moviola@gmail.com

2 Doutora e mestre em Estudos Comparatistas pela Universidade de Lisboa, Portugal. Atualmente na Universidade de Lisboa, Centro de Estudos Comparatistas, Lisboa, Portugal. ORCID: https://orcid.org/oooo-0002-4973-5038. E-mail: soniamiceli@campus.ul.pt 3 CARVALHO, Bernardo. [Entrevista cedida a] Beatriz Resende. Z Cultural - Revista do Programa Avançado de Cultura Contemporânea. Rio de Janeiro. 2007. Disponível em: http://revistazcultural.pacc.ufrj.br/entrevista-com-bernardo-carvalho/. Acesso em: 20 maio 2017.
} 
Também acho que tem um encanto pelo fracasso, que vem da minha formação, que passa muito pela leitura da literatura moderna do século XX, pelo projeto da modernidade... Embora eu não goste especialmente dos surrealistas, acho que está muito presente no projeto surrealista, também no Michel Leiris, essa ideia de fazer uma obra cujo resultado estará sempre aquém do projeto da obra. Isso já aparecia nos simbolistas, no Mallarmé. A obra é irrealizável, o que se realiza é uma alusão possível à obra, e há uma beleza nisso, que é quase religiosa (Santo Agostinho escreveu, nas suas Confissões, que a verdade da comunicação com Deus passa pela recusa das convenções que garantem a própria comunicação, a começar pela linguagem). O que você faz, então, para ser verdadeiro, precisa estar sempre além das convenções e aquém dos ideais que essas convenções estabelecem e, por isso, é sempre uma forma de fracasso, é sempre falhado, porque é uma coisa que não se realiza nunca, quer dizer, é um projeto que alude ao inatingível. $\mathrm{E}$ as lacunas estão aí, justamente, porque esse projeto não pode se realizar sem a participação do outro, que é sempre uma projeção ou uma ausência. Em contrapartida, o que vem agora junto com a hegemonia do mercado é a ideia de um leitor-cliente, é uma obra que obedece a certas convenções como condição de realização de um ideal, é um novo academicismo; é um modelo que obedece a certas normas absolutas para a satisfação do leitor e a realização da obra. Isso passou a ser critério absoluto de julgamento da prosa de ficção. O estilo que melhor atende a uma literatura mais massificada é aquele em que o leitor precisa fazer menos esforço de reflexão e participação, o que torna mais natural a leitura e permite ao leitor entrar no livro de uma forma mais transparente e imperceptível, porque o que está escrito ali corresponde a uma mimese psicológica da realidade que ele conhece - e, como cliente, o leitor não pode ser contrariado. A lacuna corresponde, ao contrário, a uma falha nessa representação, a uma ideia de projeto que se realiza ao fracassar, ao pôr a convenção em questão, invocando o leitor. O fracasso está embutido na própria origem desse projeto.
SONIA AURORA MICELI - Em Simpatia pelo demônio há uma frase que me chamou a atenção: "a intenção do texto literário não tem nada a ver com a nossa experiência”. A intenção e a experiência são de quem escreve ou de quem lê? Li isto como a ideia de que, seja qual for a intenção do escritor, se ela existir, a tendência que muitos leitores têm é para preencher o texto de acordo com a sua experiência. Aí lembrei-me da epígrafe de $\boldsymbol{O}$ sol se põe em São Paulo, de Valéry, e pareceu-me que os estranhos discursos, dirigidos para alguém que não está lá e procedentes de alguém que não se sabe bem quem é, poderiam ser uma boa metáfora para o discurso da literatura, em que o autor que se torna outrem e também está a falar para alguém que, ao ler o livro, vive uma experiência que não é a dele. A ideia é que a literatura seja uma experiência de estranhamento, mais do que de reconhecimento.

BC - Algum resquício de reconhecimento você tem que ter, porque senão não consegue se relacionar com aquilo. O problema é que um dos lugares-comuns desse modelo de literatura de reconhecimento é a empatia, uma coisa básica da psicologia, é você só gostar do que lhe desperta afinidade. Hoje mesmo (26 mar. de 2017) havia na Folha de São Paulo a entrevista do cientista cognitivo americano Paul Bloom, dizendo que a empatia provoca as piores coisas no mundo, porque, dentre as relações que você pode estabelecer com o outro, ela é a mais imediata e a menos reflexiva. O que me interessa como leitor é uma literatura que produza uma relação mediada e de reflexão com o mundo, e o que acontece hoje, cada vez mais, é uma literatura que tende a solapar a possibilidade de uma relação reflexiva com o mundo, dando ao leitor esse bônus de que o leitor não pode ser questionado, não pode ser posto à prova. Não sei mais o que a frase do Simpatia pelo demônio quer dizer, mas a frase do Valéry é a definição do que é poesia. Acho que tem uma correspondência.

Ao mesmo tempo, fico um pouco constrangido quando falo das coisas que escrevo, porque parece que tenho domínio absoluto sobre tudo, que tudo foi pensado e programado. Não foi. Inclusive essa frase é como outras que na realidade não entendo e que 
de repente me vêm à cabeça. Se tem uma coisa que é essencial nesse livro, ela está justamente nesses pontos que para mim são incompreensíveis, que têm algum sentido, funcionam de algum jeito ali, mas é um sentido ambíguo, que permite várias leituras. Quando a escrevi, talvez eu soubesse o que essa frase queria dizer. Hoje não sei mais, e é interessante que eu tenha perdido o controle sobre o sentido.

CRF - Os autores que participaram do romantismo e do modernismo brasileiro estiveram no centro de acalorados debates acerca da construção de uma "identidade nacional". Com o declínio das grandes narrativas nacionais, a literatura passa, em parte, a evocar não mais a unidade nacional, mas a pluralidade de identidades. Como você encara essa questão das “identidades" - no plural -, e qual a importância do fazer literário nos dias atuais?

BC - Uma coisa essencial aos meus livros é o incômodo com a ideia de identidade, que é vista como um artifício ou uma muleta. É claro que é mais confortável acreditar em uma identidade e seria impossível viver em grupo, viver em sociedade, sem identidade. Não há organização social nem luta possível sem identidade. O problema é que, a meu ver, o escritor está ligado à busca de uma verdade do texto (não necessariamente "o que" narra ou representa o texto, mas "como" ele narra e representa) que não tem nada a ver com identidade enquanto instrumento de organização social. Cientistas cognitivos recentemente chegaram à conclusão de que a razão, por exemplo, não te leva necessariamente à verdade, a razão é um instrumento que só o homem desenvolveu, entre todos os animais, para poder trabalhar em grupo, em sociedade. É um instrumento de persuasão, sem o qual é impossível você argumentar e convencer o outro. Mas você não convence o outro apenas de uma verdade, pode ser uma mentira absurda também, um negócio totalmente descabido. O importante da razão é que ela é uma espécie de cimento social que permite que nós trabalhemos em grupo, que um convença o outro a trabalhar junto. Eu penso que o escritor, até pela possibilidade e pela definição de um trabalho que é solitário, dissociado, se ele radicalizar esse trabalho, vai necessariamente pôr em questão esses instrumentos de funcionamento social e que podem ser simples muletas, ou podem ajudar no caminho das ciências e nas organizações de grupos sociais, e que são fundamentais nas lutas pelos direitos civis, mas também podem te afastar radicalmente da verdade. A literatura tem o poder inverso, se você radicalizar esse projeto, de provocar dissenso, de desestabilizar os consensos. Ela não tem que ser edificante, não está aí para criar o bem; ela está aí para, justamente, quebrar esse negócio da reprodução e do reconhecimento, para alargar o mundo e a compreensão do mundo, pela diferença, pelo desvio. Então, se ela tem uma função, a função é contrária a estas ideias de empatia, de identificação, de criação de identidade, essa coisa de representatividade, tão central aos estudos culturais. Nesse sentido, eu não consigo entender como é que se pode atrelar a literatura necessariamente a um projeto de identidade nacional, uma vez que esse projeto pressupõe um consenso e um artifício. É claro que um país no qual todos os grupos sociais, incluindo aí as minorias, estão representados na literatura, é um país mais justo e mais democrático. Visibilidade gera transformação. Mas eu também vejo uma impostura em subjugar a literatura à representação das identidades, achando que assim vai resolver o racismo e as desigualdades sociais. Se você fizer uma análise sociológica e constatar que os negros não estão representados na literatura de um país de população negra como o Brasil, vai ver que essa não representação diz muito sobre o racismo e as desigualdades sociais, a começar pela educação. Por outro lado, clamar pela representação dos negros nessa literatura, sem combater a causa dessa falta, não faz essa literatura ser melhor ou pior, nem resolve $o$ problema da desigualdade e do racismo. A literatura está em um lugar mais reflexivo e mais mediado do que a representação direta da democracia representativa. Penso que, se você subjugar os critérios de avaliação da literatura à representação imediata, quantitativa, que ela faz dos grupos sociais, vai perder um aspecto que para mim é fundamental, do ponto de vista político inclusive, que é essa questão do dissenso, de quebrar os consensos e as identidades. 
SAM - Quase todos os seus livros têm alguma ligação com o visual, inclusive há muitas personagens que são fotógrafas. Tem um ensaio da Natália Brizuela $^{4}$, em que ela fala da forma como literatura pode ser pensada a partir, ou como ela diz no título, depois da fotografia, e ela se refere justamente a Nove Noites, sugerindo que a predominância discursiva fotográfica na literatura contemporânea não serve ao seu caráter documental, mas sim à opacidade que lhe é própria, ao que ela esconde muito mais do que revela. É neste sentido que ela entende uma declaração tua, em que dizias que a literatura era uma afirmação de verdades, então não seria uma verdade revelada, no sentido até religioso do termo, poderíamos dizer, porque a revelação, em muitos casos não acontece. Penso, por exemplo, em Mongólia, em que a ideia de revelação tem uma dupla valência, podemos pensar na revelação das fotografias do Desajustado, que não acontece, porque não chegam sequer a ser tiradas, mas também na revelação do Antibuda... Podemos pensar em um conceito de verdade, como verdade não revelada, como a fotografia não revelada, ou que, apesar de revelada, mantém a sua opacidade.

BC - Isso tem tudo a ver, inclusive no Nove Noites, que tem aquela foto de grupo, em que a personagem principal está ausente, e essa ideia de falta, de não aparecer, é fundamental nesse retrato onde estão todas as pessoas com quem o ausente tinha contato mais íntimo no Rio de Janeiro. Ou seja, é um retrato do ausente, à revelia. Tem um projeto incrível de uma fotógrafa americana chamada Taryn Simon, em que há uma série de fotografias de pessoas que foram condenadas por crimes que não cometeram e cuja condenação foi baseada no reconhecimento de fotografias. As vítimas "reconheceram" os supostos criminosos pelas imagens e esses inocentes foram condenados e passaram anos presos, vinte anos às vezes, até aparecer o teste de DNA e ficar provado que tinham sido condenados por engano, por causa da imagem fotográfica usada como prova imediata da verdade. A ideia da fotógrafa é que toda imagem pre- cisa de mediação. Em uma exposição dela que vi em Berlim, as séries de imagens vinham acompanhadas de textos explicativos muito complexos e intrincados. Era o contrário da ideia de que a fotografia fala por si, o contrário de uma relação imediata com a imagem, sem nenhum interposto reflexivo. Nas fotos dela, o texto pode ser até mais importante que a foto: é pelo texto que a imagem se revela. Ou seja, a fotografia em si não apenas não revela como confunde e pode ser letal, dependendo do uso que se fizer dela. No trabalho dessa fotógrafa, há essa ideia da ambiguidade, do paradoxo da fotografia como opacidade, como desaparecimento, como não reconhecimento.

SAM - É, de fato, notável a quantidade de personagens fotógrafas na tua obra...

BC - Tenho uma obsessão pela imagem e pela ideia dessa imagem não como simples revelação, mas como espécie de elemento bruto, em que tudo está embutido, mas onde tudo está por dizer. Ausência e presença ao mesmo tempo. O que me atrai no documento é aquela dimensão secundária, muitas vezes irrelevante à primeira vista, que escapa à intenção do fotógrafo e que o Roland Barthes destaca no Câmara Clara (1980). Toda fotografia tem um traço documental, um traço do real, que revela a despeito do que ela pretendia revelar ou esconder. É o que faz a riqueza da imagem fotográfica. Tem a ver com um dos efeitos básicos da fotografia, que é congelar a imagem de uma pessoa que desapareceu, a fotografia como representação da morte em vida. Na foto de grupo do Nove Noites, não apenas o Buell Quain, mas os outros, que estavam presentes e vivos no momento do retrato, agora também são ausências, também estão mortos, é um mundo fantasmagórico. Ao contrário da ideia de que ela tem algo imediato a dizer, eu acho que toda fotografia tem uma narrativa embutida, escondida, e um lado romanesco também, isso é essencial à fotografia

CRF - Em seus livros, as marcações e os contatos com a alteridade são constantes, seja a alteridade indígena, mongol, japonesa ou russa.

BRIZUELA, Natalia. Depois da fotografia. Uma literatura fora de si. Trad.: Carlos Nougué. Rio de Janeiro: Rocco, 2014. 
Encaro como uma forma de concretizar questões problemáticas existenciais e não tanto como uma preocupação de natureza cultural e identitária, estritamente antropológica. Pensando na ideia de Viveiros de Castro ${ }^{5}$, segundo a qual a imagem pertence sempre a quem a recebe, ou seja, o outro, pode ser pertinente lembrar que a maioria dos personagens de seus romances não são identificados pelo nome, que, em vários casos desconhecemos, mas sim por alcunhas que outros lhes atribuíram. Podemos ver isso como uma forma de negar a possibilidade de qualquer projeto identitário? $\mathrm{Ou}$ seja, a literatura como campo de construção de alteridade, até o próprio se tornar outrem...

$\mathrm{BC}-\mathrm{A}$ relação com o outro que mais me interessa tem menos a ver com empatia do que com fricção. A literatura contemporânea desenvolveu uma relação de boas intenções como o outro, reduzido a vítima, que me incomoda muito. Até na relação com os índios - que de fato sempre foram vítimas de uma sociedade violenta e espoliadora como a brasileira - me interessa mais o mal-entendido do que o bom entendimento do outro. Me interessa mais a fricção um narrador que pode ser racista na sua relação com o outro, por exemplo - na qual esse embate esteja presente, um confronto com o real mais do que uma relação domesticada e paternalista, resultado de uma representação justa e correta do ponto de vista moral, mas na qual o outro aparece como vítima. Dito assim, pode parecer que eu esteja no lugar do opressor, mas não é nada disso, inclusive na relação com o índio representada na parte mais patética e grotesca do Nove Noites, por exemplo, quando o narrador visita a aldeia e tem aquele delírio paranoico dele. Ele trata o índio como a um igual, ele teme o índio, mas se recusa a estabelecer uma relação paternalista, não dá nada para o índio, não acha que esteja num lugar diferente do índio, ele se comporta como se fosse irmão do índio e ainda assim não entende nada. Isso me interessa. Ele lida com o outro, com todos os mal-entendidos possíveis, mas como se estivessem...

\section{SAM - No mesmo nível..}

BC - Sim, porque isso gera a possibilidade do conflito e do mal-entendido, que é material romanesco por excelência, desde o Quixote. É importante que eu vá para o Japão e não entenda nada. Cair no preconceito, cair no mal-entendido e a partir daí criar esse conflito e esse confronto que põe o ponto de vista subjetivo do narrador em questão e em perspectiva.

CRF - Em Nove Noites, há uma verbalizada impossibilidade de comunicação, quando o narrador fala que o índio sabia exatamente o que ele estava falando, mas nenhum dos dois queria se entender, havia uma má vontade mútua nessa comunicação...

BC - Essa passagem é importante porque ele está lendo um livro e quer dizer para o índio o que é a literatura na sociedade dele, e é grotesco porque ao definir a literatura para o índio ele já percebe a fragilidade daquela definição. Tem um lugar estranho aí, porque o narrador emite uma definição que corresponde aos meus desejos de autor do que a literatura deve ser, ao que eu gostaria que a literatura fosse e, ao mesmo tempo, no contato com índio, isso fica totalmente fragilizado. A consciência do ridículo dessa definição está embutida no confronto. Então, esse discurso que ao mesmo tempo é peremptório, de um certo ponto de vista, porque exprime uma definição quase ortodoxa ou, sei lá, dogmática ou programática do que deve ser a literatura, vai sendo questionado pelo confronto com o outro. E isso acontece até nas coisas que são mais caras e mais preciosas para mim, para o autor. O livro põe em questão o tempo inteiro o lugar do emissor, do enunciador, do que seria a verdade ou a ideologia do autor. Mas enfim, isso era só uma digressão...

SAM - Muitas vezes os narradores dos teus romances apropriam-se de histórias de outros, por meio da circulação de cartas, diários e todo tipo de papéis, algo que tem um pouco a ver com aquela ideia d'O Sol, de que ninguém pode contar a própria

5 CASTRO, Eduardo Viveiros de. A identidade na era de sua reprodutibilidade técnica. [Entrevista cedida a] Pedro Peixoto Ferreira. Revista Nada, Lisboa n. ${ }^{\circ}$ 11. P.34-51. Editora UR - Urbanidade Real, lda, 2008. 
história, só conta a história dos outros. Por quê? Por que não podemos contar a nossa história e como funciona esse mecanismo de apropriação de histórias?

BC - Tem a ver com a duplicação do eu e do outro, da ideia de que a literatura é um pouco isso, uma possibilidade de você criar um eu que vai ser sempre outro. A minha história está no outro também, sempre, porque o outro é projeção, porque o outro é subjetividade também. Não é um beco sem saída, porque a ideia é que mesmo a impossibilidade do conhecimento do outro na verdade permite que você faça literatura, não só que você imagine, mas que essa imaginação seja também uma forma de conhecimento. Não é simplesmente uma apropriação do outro, ou uma submissão do outro a um estado de uso ou de opressão, é uma forma de confronto, mas que inclui a subjetividade e que permite uma passagem de conhecimento para um outro lugar, que não é o conhecimento direto e que está amarrado por esse reflexo, por esse jogo de espelhos.

CRF - O índio tem um papel fundamental na história literária brasileira, desde o índio romantizado de José de Alencar, passando pela inclusão de lendas e conceitos indígenas do modernismo do Mário de Andrade e do Oswald de Andrade, até Guimarães Rosa, em Meu tio o Iauaretê, Darcy Ribeiro, com Maíra e, mais recentemente, com Meu destino é ser onça (2009), do Alberto Mussa, e as obras de autores indígenas como Daniel Munduruku, Graça Graúna e Eliane Potiguara, dentre outros. Como você situa Nove Noites dentro dessa historiografia literária, que tem a representação e a cultura indígena em seu cerne temático?

BC - Para escrever o livro eu tinha que me descolar dessa tradição e do peso histórico dessa representação na literatura brasileira. Ou seja, para poder escrever eu precisava não ter consciência de qual seria a diferença ou semelhança que essa representação teria em relação a essa tradição. A condição de possibilidade do romance foi justamente ignorar o que tinha sido feito antes em termos de representação indígena. É possível que eu tenha chegado, talvez, em algum momento, até a ignorar completamente, por exemplo, Guimarães Rosa e mesmo Darcy Ribeiro e pensar que só haveria no Brasil, na literatura, a representação de um índio idealizado. Mas, isso só me ocorre agora, é como se eu tivesse bloqueado a possibilidade de qualquer tipo de representação do índio mais interessante ou mais sofisticada do que a que tinha sido feita no romantismo. Eu não parei para pensar em que lugar o Nove Noites se situa, a posteriori, nessa tradição. O que eu posso dizer é que na hora em que o Nove Noites foi escrito, minha ideia era justamente não ter isso na cabeça, não pensar de jeito nenhum nessa tradição. Isso também vale em relação à própria possibilidade de fazer literatura no Brasil. Tenho uma espécie de mecanismo de defesa e de sobrevivência, que me põe fora do lugar onde estou. Me põe fora da literatura brasileira, como se não houvesse literatura brasileira antes de mim, ou durante, ou simultânea. Para que eu possa escrever, justamente, preciso não pensar que estou inserido no contexto da tradição da literatura brasileira.

SAM - É um problema também de língua, de língua mesmo portuguesa, ou seja, tu gostas, por exemplo, mais de ler autores de outras línguas, certo? O que lês?

BC - É muito seletivo o tipo de leitura que eu faço e tem a ver com acasos, com encontros que são felizes casualidades e coincidências e que, na verdade, servem todos para a criação de uma espécie de corpo que é o meu projeto, a minha literatura. Acabei descobrindo que, sem que eu tivesse planejado nada, se é que há uma literatura com a qual eu mais me relaciono, é curiosamente uma literatura cuja língua original eu não falo, que é o alemão. Existe uma correspondência entre o que eu faço e uma certa tradição alemã. Só depois de muito tempo é que me dei conta disso. É uma tradição que vem desde a obra do Heinrich von Kleist, por exemplo, que, apesar de aparentemente não ser ensaística ou filosófica, acaba por o ser, tem esse substrato filosófico. Além disso, acho que é uma literatura do fracasso e isso sempre me fascinou. Isso aparece no Kafka também, essa ideia de uma literatura menor, que é uma coisa que o Deleuze observou sobre o Kafka e o Kleist. 
Comparado com o Goethe, por exemplo, o Kleist escreveu uma literatura totalmente fragilizada e falhada e, no entanto, é de uma força e de uma potência incríveis. E é uma potência já naquela época, por exemplo, contra a identidade nacional que o Goethe representava tão bem. Então, tem vários elementos que me interessam e que, sem que eu tivesse me dado conta, me influenciaram muito, embora aparentemente não haja nenhuma correspondência. $\mathrm{Na}$ literatura brasileira, tenho um encanto especial por coisas que são totalmente diversas do que eu faço, como o Guimarães Rosa. Tenho fascínio pelo que é totalmente oposto a mim, inclusive de um ponto de vista moral, talvez, político, porque, por exemplo, eu acho que o Guimarães Rosa faz um elogio do homem, uma literatura otimista, do bem. E tem algum problema na minha literatura, que eu acho que está mais ligado ao pessimismo do Machado, embora eu, como leitor, me encante muito mais com o Guimarães Rosa. A minha literatura tende a ver o homem como um ser essencialmente suicida.

SAM - Essa questão surge em Aberração e em Simpatia pelo demônio. Há duas personagens muito parecidas, que são o æ, mesmo no primeiro conto do livro, e o chihuahua. Ambas são personagens narcisistas, cruéis e que têm uma particularidade, a de imitar os sentimentos dos outros. O que te atrai nessas personagens?

BC - Tem uma coisa muito forte, que me fascina nessa personagem predadora. O chihuahua, em si, é ninguém. Ele é um reflexo e um rebatimento, como já dava a entender morfologicamente a própria letra que servia de nome a æ. Ele mimetiza o outro e, ao mimetizá-lo, mata o outro, quer dizer, é como se a personagem fosse ao mesmo tempo um espelho e uma ilusão, uma armadilha que põe em jogo e em questão o princípio das identidades. E essa personagem do chihuahua... é engraçado, eu não tinha pensado nisso, mas a posteriori, me lembrei, acho que cheguei a fazer essa conexão com Aberração em algum momento, mas logo esqueci, não era uma coisa muito consciente. Enquanto escrevia o Simpatia pelo Demônio, li sobre o que uma escola contemporânea da psicanálise define como "perverso narcisista" e que corresponde muito ao chihuahua. Esse personagem existe no mundo, é um tipo mais comum do que se imagina e é muito difícil sair incólume de um contato com ele. Esse personagem já me fascinava no Aberração. Eu não sei te dizer por quê, mas acho que tem a ver com essa ideia de um indivíduo cuja identidade depende da emulação e da destruição da identidade do outro. É uma relação que leva à morte do outro. Quer dizer, ele fisga o outro, ele imita o outro, ele corresponde à projeção do outro e é isso que é terrível na perversão, porque o amor depende de projeção. Quando você se apaixona, vai necessariamente projetar alguma coisa sua, a sua fantasia, no objeto do seu desejo. A perversão desse personagem é que ele corresponde a essa projeção, sendo que não há nada por trás, ele é uma tela branca, na verdade ele é apenas um espelho diante de outro espelho.

\section{SAM - Imagina-se como o outro o imagina.}

BC - É, ele é um reflexo, ele apenas rebate a projeção do outro, que volta para o outro, em vez de se constituir como uma pessoa real. É uma queda absoluta, sem fim e sem anteparo, não tem como sair desse lugar, porque você diz "eu te amo" e ouve o outro a corresponder ao que você disse, mas na verdade é você dizendo "eu te amo" diante de um espelho. Esse personagem é fascinante porque quebra a coisa da correspondência das identidades, não há o outro, só o mesmo, o outro é espelho. É uma realidade que não se realiza porque é só projeção da subjetividade e é estranhíssimo, como se o real tivesse se convertido em um empecilho de contato com o real, como se o real fosse só um espelho o tempo inteiro. De qualquer forma, Simpatia pelo demônio não foi escrito como ilustração dessa ou de qualquer outra teoria. A situação do romance também poderia servir, por exemplo, de alegoria para essa outra obsessão minha, de um ser que é autodestrutivo. O Rato é um cara de meia-idade; dentre os personagens, é o mais próximo de mim no livro. É um sujeito que de repente está diante da morte, cada vez mais próximo da morte, e que diz: "Não quero morrer, quero renovar a vida”. Mas, para renovar a vida, ele vai buscar justamente a paixão que o mata. 
CRF - Em entrevista a Flávio Moura ${ }^{6}$, você fala que a ideia do romance Nove Noites era ele se aproximar do espírito de um livro de jornalismo, mas apenas se aproximar, uma vez que à diferença de suas outras obras, em que a linguagem estaria a procura da história, em Nove Noites a história estaria a priori. Além disso, a representação dos índios na obra está mediada pelos tensionamentos narrativos entre verdade e mentira, real e ficcional. Essa tensão entre realidade e ficção fará dele, segundo você mesmo disse, uma "literatura à maneira dos índios”, pois mantém essa dúvida para o leitor. Como se deu essa busca pela linguagem e o que seria essa "literatura à maneira dos índios"?

BC - É um velho clichê dizer que os índios mentem, que eles sempre correspondem ao que acham que você quer que eles façam ou digam. Teria um pouco a ver talvez com essa ideia do personagem perverso, do espelho, só que no caso do índio, o resultado seria uma opacidade, e não um reflexo, porque a projeção seria dele. O índio supõe que você queira ouvir uma certa história e conta para você aquela história. Só que a história, que segundo ele você supostamente queria ouvir, atrapalha e impossibilita o que na verdade você quer descobrir, cria o paradoxo de um espelho opaco. Tem a ver com uma impossibilidade de conhecimento do real. Você vai em busca de uma resposta e se depara com um espelho que reproduz a sua pergunta ao infinito. É terrível, porque é um mundo incognoscível, um mundo da opacidade permanente. É possível que eu tenha incorporado de algum jeito esse mecanismo na forma e na linguagem do livro, com a ambiguidade entre fato e ficção, por exemplo, já não sei. A outra coisa é que a leitura de uma única frase do artigo da Mariza Corrêa, como é narrado no romance, despertou em mim alguma coisa que até aquele momento estava inconsciente. A frase detonou a busca. É como se eu estivesse apaixonado, absolutamente obcecado pelo personagem e pela vontade de descobrir por que ele teria se matado. Então, isso aí pôs o objeto na frente da linguagem.
Normalmente, quando escrevo um romance, procedo por camadas, a própria linguagem vai criando aos poucos a realidade da história. Ali, essa realidade foi criada por uma paixão que precedia a linguagem.

Por exemplo, o que eu fiz aqui em Lisboa: ao iniciar um novo romance, primeiro escrevo um texto que dá a realidade do livro e, conforme vou reescrevendo e afinando as coisas, a própria linguagem vai mudando o curso do que estou dizendo. Mudando a ponto de inverter completamente a história que eu estava contando e de levá-la para outro lado, com os personagens se transformando em coisas completamente diferentes. Em um único parágrafo, posso transformar um personagem que era branco e louro em negro ou aborígene, mas pela linguagem. É a linguagem que determina a realidade, o objeto sobre o qual estou escrevendo. O que aconteceu em Nove Noites é que essa etapa foi feita na vida, antes da linguagem, na obsessão pelo morto. Quando eu parei para escrever, essa primeira camada, essa primeira etapa da criação do romance já estava pronta. E havia uma urgência que eu não tenho normalmente na hora de escrever um livro. Então, acho que isso aí talvez remeta a um procedimento jornalístico, como se já houvesse uma realidade a ser relatada. Embora fosse uma realidade criada de forma obsessiva, apaixonada, subjetiva. Ou seja, não era a realidade; eu já estava criando ficção antes da escrita. A própria experiência se confundia com a ficção.

A partir do Nove Noites criei uma espécie de método baseado no medo, em grande parte inspirado pela leitura das notas de campo que o Buell Quain deixou. Ele decidiu visitar os Trumai, mesmo sem autorização, contra as determinações do Estado Novo. No caminho, ele caiu doente. Quando chegou à aldeia, febril e delirante, encontrou um povo em vias de extinção, reduzido a um punhado de indivíduos que viviam em estado de pânico coletivo. O pânico desses índios contaminou a apreensão que o antropólogo, representante da razão e da ciência, podia ter deles. O estado físico e mental do antropólogo

6 CARVAlHO, Bernardo. A trama traiçoeira de Nove Noites. [Entrevista cedida a] Flávio Moura. Revista Trópico, São Paulo, 2003. Disponível em: http://www.revistatropico.com.br/tropico/html/textos/1586,1.shl. Acesso em: 20 maio 2017. 
tornou-o poroso ao seu objeto de estudo, a ponto de se deixar contaminar por ele, confundindo sujeito e objeto em uma relação simbiótica. O antropólogo passou a viver o mesmo pânico que aquela sociedade vivia, as mesmas alucinações. Depois de entrar em contato com essas notas, achei que eu só poderia descobrir o que teria levado esse sujeito a se matar meses depois se sentisse um pânico análogo ao que ele sofreu entre os Trumai. Fui à aldeia dos Krahô com a determinação de sentir medo. E daí em diante isso passou a ser uma espécie de método literário, contaminando a experiência e a realidade com a subjetividade da ficção, antes da linguagem, antes da escrita. Ou seja, eu tinha que ir para a aldeia, mas não para viver uma experiência antropológica ou jornalística, e sim uma experiência quase teatral. Como se pudesse encarnar o antropólogo, para viver um medo deslocado, porque anacrônico. Então, essa é uma outra forma de lidar com a linguagem, quando eu de fato comecei a escrever o livro, parecia que a linguagem, que o texto já estava pronto.

CRF - Você está costurando a relação entre autor e narrador como se não se diferenciassem, é isso?

BC - A exemplo do que aconteceu com o antropólogo entre os Trumai, é um autor que se deixa contaminar pela ficção antes mesmo de escrevê-la. Quando escrevi Nove Noites, essa ideia de representação e, sobretudo de representação do autor na literatura, estava muito presente, por conta do multiculturalismo. A literatura estava sendo reduzida à representação do autor, que podia ser negro, gay, mulher ou o que seja. E isso queria dizer que um autor gay branco estava condenado a corresponder ao universo pressuposto de um autor gay branco. A minha ideia a partir desse romance era justamente brincar com essa norma de literatura como expressão da experiência do autor, fazendo a experiência do autor já ser ficção. Ou seja, é o autor que está indo visitar os índios, mas é também um personagem, porque ele está indo para lá com um projeto subje- tivo, ele vai descrever um teatro, que é ele tentando se pôr na pele do objeto da sua paixão, protagonista morto da história que ele vai escrever. É grotesco, o negócio não funciona, claro, mas essa brincadeira faz parte e já é, de alguma forma, o livro. Isso não quer dizer que a experiência seja totalmente fantasiosa, subjetiva; ela tem que ter esse confronto com o real de alguma forma. Ela exprime uma situação real com o índio, mas que está toda contaminada por uma subjetividade, pelo projeto de escrever um romance, que faz com que ela seja também, de alguma forma, artificiosa. Se alguém resolvesse me matar ali, é bem possível que eu morresse, porque não estava no mundo da ficção e da fantasia, mas havia a ambiguidade de ir para esse mundo real, onde posso morrer, onde podem me matar, me cortar, me machucar, mas com um ponto de vista romanesco, ficcional. Então, é autor e não é. Essa ambiguidade abre um paradoxo nessa história da experiência do autor e da literatura reduzida à expressão dessa experiência. O livro fala disso o tempo todo. O problema é que a leitura que tende a reduzir a ficção a relato e autobiografia é muito forte.

CRF - Diferente do Alcir Pecora que classifica o Nove Noites como um "estranho romance policial"7, eu o vejo mais como uma espécie de versão contemporânea do romance de aventura do final do século XIX, em que a personagem principal é marcada pelo contato com a sua alteridade mais radical, como em $O$ Coração das Trevas (1899), de Joseph Conrad. Em Nove Noites, percebo muitos momentos de uma presença quase fantasmagórica do Coração das Trevas, especialmente quando a narrativa se situa entre os índios Krahôs. Apesar das diferenças na escritura formal do romance como o fato de ter um narrador mediador muito presente - achas que Nove Noites pode ser considerado como um encontro ambíguo e desconcertante do homem branco no início do século XXI com a alteridade indígena? 
BC - Conrad era um homem que, embora não fosse inglês, estava escrevendo do ponto de vista da metrópole, do maior império da época, quer dizer, era de fato uma relação com o outro. No meu caso, embora haja alteridade, é uma alteridade que está contaminada por uma proximidade muito maior, já que esse outro não é totalmente outro. É mais ambíguo.

CRF - Eu tive a impressão de que esse outro era completamente outro...

BC - Pode ser... mas para mim, a ideia é que esse outro não é tão outro assim, inclusive na forma como o narrador se apresenta à aldeia, como um igual, e a própria possibilidade de ter uma relação com o outro que é uma relação de conflito, como se fosse um irmão e estivesse disputando um brinquedo com o índio. Enfim, o narrador expressar raiva contra o índio, xingar o índio, eu, o narrador, no caso, mas o autor também, acho que é muito diferente da relação do Conrad com o outro, que, embora não seja paternalista, supõe uma alteridade absoluta. Para um brasileiro como eu, talvez a alteridade absoluta esteja muito mais no Quain, no antropólogo americano, do que no índio. Isso tem a ver com os outros livros, como o Simpatia pelo Demônio, com uma alteridade amorosa. O outro é incognoscível. O Nove Noites é a narrativa de um desespero obcecado, o relato da paixão por um morto. O narrador vai atrás desse cara, como se ele estivesse numa relação apaixonada, querendo descobrir o que estava na cabeça do outro.

CRF - Mas esse outro para mim, estaria mais no âmbito desse espelho opaco, o personagem do Quain me parece mais esse espelho opaco que reflete a subjetividade do que uma alteridade, que me parece ocupada pelo indígena no Nove Noites especificamente.

BC - Acho que a alteridade na minha literatura é esse lugar paradoxal do reflexo que é opaco, mas ao mesmo tempo é espelho, quer dizer, é você o tempo inteiro, é "outro" e é "eu”. Isso é interessante na literatura. Essa ideia do outro - isso é básico na literatura - que também é eu. Só para reforçar, tem a coisa do Coração das Trevas, mas tem também outro conto do Conrad citado no Nove Noites, que se chama O Companheiro Secreto (1909) e, é fundamental porque trata da relação com o outro como duplo. E no Simpatia pelo demônio essa situação se repete, com o cara coberto de explosivos no quarto de hotel onde está o narrador. É a partir desse encontro que o narrador vai contar a sua história. É uma espécie de reencenação da situação de O Companheiro Secreto, porque o narrador dá suas roupas ao homem com explosivos e é como se a identidade mudasse, como se houvesse uma transferência de espelho com o outro. O homem com os explosivos não fala a mesma língua, pode ser visto como o outro absoluto. Mas a ideia do outro, mesmo no Conrad, tem sempre uma relação de espelho, que envolve a subjetividade. Tem projeção dos dois lados, projeção e reflexo, e essa relação me interessa, porque é uma relação de conhecimento, ou melhor, de impossibilidade de conhecimento, e ao mesmo tempo de contaminação e de fusão. É a história do Buell Quain na aldeia dos Trumai. O que ocorre aí é uma fusão com o delírio social, com a alucinação do outro, e você não sabe o que está contaminando o quê, porque o próprio sujeito da razão também está doente. Ele chega ao lugar do delírio e do pânico, mas já chega delirante, quer dizer, tem uma coincidência aí, como se a realidade que ele fosse buscar correspondesse ao estado subjetivo dele, né? Há essa contaminação também no Conrad. Como eu disse lá em Coimbra ${ }^{8}$, me parece que hoje há mais uma relação de subserviência com o outro, como se o outro fosse sempre vítima e tivesse que ser tratado com paternalismo e a literatura tivesse que se ajoelhar diante do outro, no sentido de estar à mercê dessa representação. Eu acho que a representação do outro passa por uma questão subjetiva, que é uma relação de projeção, uma relação de subjetividade bastante complexa. $\mathrm{E}$ a literatura não pode abrir mão dessa complexidade.

8 O autor participou de uma conversa sobre a sua obra no Instituto de Estudos Brasileiros da Universidade de Coimbra, no dia 22 de março de 2017. 
SAM - Simpatia pelo Demônio é muito diferente da maioria dos teus outros livros, porque aqui está tudo explicado. Normalmente tu tens um final sempre ambíguo, que convida à releitura... Por que dessa vez quiseste explicar tudo?

BC - Porque um dos preceitos do realismo psicológico, que tem muito a ver com o mundo anglo-saxão, mas acabou sendo exportado para o resto do mundo e se tornando mais ou menos o modelo hegemônico hoje, às vezes degenerando em normas academicistas do tipo "todo bom romance tem personagens de carne e osso", enfim, um dos principais preceitos desse romance realista e psicológico determina que o bom romance não diz, ele mostra. Isso já estava no Tchékhov, de uma forma maravilhosa, mas acabou virando uma espécie de dogma, como se a narrativa literária fosse roteiro de cinema. Não gosto muito de dogmas e normas. O Proust, que eu estava lendo na época, é o contrário disso. Ele é o ápice do realismo, mas o narrador proustiano diz o que está pensando e sentindo o tempo todo, com uma precisão jamais vista. É o ápice do realismo reflexivo. Por isso, não basta mostrar, é preciso dizer e analisar a fundo, até as últimas consequências. O narrador passa a exprimir esses sentimentos com todas as letras, e a linguagem se forma dessa expressão. É uma tentativa desesperada de entender e dar nome aos sentimentos humanos. Eu queria fazer um livro em que tudo fosse dito, quase como uma reação a esse modelo de realismo empobrecido em que dizer é o pecado mais absoluto. Eu queria analisar, tentar compreender os sentimentos. Embora o narrador seja em terceira pessoa, ele está colado ao personagem do Rato. Você só vê o que o Rato vê, o que o Rato percebe. É como se a narrativa fosse um processo desesperado de compreensão do outro, no caso o chihuahua, que é incognoscível e que é o objeto do desejo do Rato. O narrador lança mão de todos os recursos que o Rato tem de literatura, de teoria, de tudo o que lhe cai na mão. É um livro em que tudo é dito e repetido e que tem a ver com a repetição obsessiva da paixão, que é espiral, sempre um giro a mais no esforço de entendimento do outro que, a despeito de tudo, continua incognoscível, é uma projeção, um fantas- ma. O chihuahua é o pivô da história, a obsessão da narrativa, mas você continua sem vê-lo no final. Por mais que o romance diga, ele não mostra. É o inverso da norma do bom realismo psicológico.

Recebido em: 31/10/2018.

Aprovado em: 9/4/2019.

Christian Fischgold é doutor (2018) em Literatura Comparada pela UERJ. Realiza pós-doutorado no Instituto de Estudos da Linguagem - UNICAMP com bolsa CNPq-Brasil (154766/2018-6). Trabalha as relações entre as literaturas africanas e a literatura brasileira, com ênfase nas representações mitológicas e relações interdisciplinares entre etnografia, literatura e linguagens audiovisuais. Membro do Grupo de Pesquisa Multi-Institucional Áfricas UERJUFRJ, e do Kaliban - Grupo de Estudos Pós-coloniais e Literatura Mundial. A realização deste trabalho contou com apoio da FAPERJ.

https://orcid.org/oooo-0002-6510-7963

E-mail: crf.moviola@gmail.com

Endereço de correspondência: Rua Pinheiro Machado, $\mathrm{n}^{0} 51$ - apto 506 - 22231-090 Rio de Janeiro - Brasil

Sonia Aurora Miceli é mestre (2011) e doutora (2017) em Estudos Comparatistas pela Universidade de Lisboa. Na sua pesquisa de doutorado, investigou as relações entre literatura e antropologia nas obras de Bernardo Carvalho e de Ruy Duarte de Carvalho. No Centro de Estudos Comparatistas, foi membro dos projetos DIIA - Diálogos Ibéricos e Iberoamericanos e Falso Movimento - Estudos sobre Escrita e Cinema. Os seus interesses de investigação incluem a literatura brasileira contemporânea, literatura e cinema, os estudos de paisagem, as relações entre literatura e antropologia. https://orcid.org/oooo-0002-4973-5038

E-mail: soniamiceli@campus.ul.pt

Endereço de correspondência: Travessa das Amoreiras a Arroios, $n^{0} 14$ - 1000-035 Lisboa Portugal 